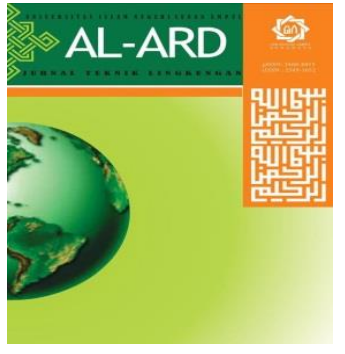

Al-Ard: Jurnal Teknik Lingkungan

Vol.6 No.1 - September 2020 (hal. 01-09)

http://jurnalsaintek.uinsby.ac.id/index.php/alard/index
Al-Ard:

Jurnal

Teknik Lingkungan

\title{
Penerapan Geometri dalam Perencanaan Instalasi Pengolahan Air Limbah Domestik : Studi Kasus Perumahan Mutiara Sartika, Kota Kendari Neles', Aryani Adami², Ilham Ilham³ ${ }^{3}$ Dwiprayogo Wibowo ${ }^{4, *}$ \\ 1,2,4 Universitas Muhammadiyah Kendari, Indonesia. \\ ${ }^{3}$ Universitas Halu Oleo, Kendari, Indonesia. dwiprayogowibowo@yahoo.com ${ }^{4}$
}

\begin{abstract}
The application of a simple geometric concept to design a domestic wastewater treatment plant (WTP) is important because it refers to a three-dimensional spatial structure to construct a storage tank. Thus in this study, we apply a simple geometric system for the design of the reservoir design which can be applied in several simple housing areas (Perumahan Mutiara Sartika-Kendari City). The results show that with the need for clean water consumption of $150 \mathrm{~L} /$ day/person with 68 housing types 36 and 5 people/house, the amount of waste generated is $40.8 \mathrm{~m}^{3} /$ day. So that the dimensions of the wastewater reservoir built are rectangular with a total volume of $79.1 \mathrm{~m}^{3}$ with an estimated residence time of 29 hours taking into account several functions of the treatment unit. Based on the results of this study, it is hoped that it can help to apply a simple WTP design for housing development.

Keywords: housing, geometry, WTP, planning, wastewater.
\end{abstract}

\begin{abstract}
Abstrak
Penerapan konsep geometri sederhana untuk mendesain suatu instalasi pengolahan air limbah (IPAL) domestik penting dilakukan karena mengacu pada bangun ruang tiga dimensi untuk membuat bak penampungan. Oleh sebab itu dalam penelitian ini, kami menerapkan sistem geometri sederhana untuk perencanaan desain bak penampungan yang dapat diaplikasikan dibeberapa kawasan perumahan sederhana (Perumahan Mutiara Sartika-Kota Kendari). Hasil menunjukkan bahwa dengan kebutuhan konsumsi air bersih sebesar $150 \mathrm{~L} /$ hari/orang dengan jumlah perumahan 68 rumah type 36 dan 5 orang/rumah maka jumlah limbah yang dihasilkan sebesar $40.8 \mathrm{~m}^{3}$ /hari. Sehingga dimensi bak penampungan air limbah yang dibangun berbentuk persegi panjang dengan total volume penampungan $79,1 \mathrm{~m}^{3}$ dengan perkiraan waktu tinggal selama 29 jam memperhatikan beberapa fungsi unit pengolahan. Berdasarkan hasil penelitian ini diharapkan dapat membantu untuk mengaplikasikan desain IPAL sederhana untuk pembangunan perumahan.
\end{abstract}

Kata Kunci: perumahan, geometri, IPAL, perencanaan, air limbah.

\section{PENDAHULUAN}

Seiring dengan pertumbuhan jumlah penduduk tentu memberikan dampak yang besar terhadap kemajuan suatu daerah atau kota dalam tatanan sektor pembangunan dan ekonomi (Arsyad, 2014). Selain itu juga, peningkatan jumlah penduduk tersebut selalu berbanding lurus dengan pertumbuhan di sektor penunjang seperti sektor pemukiman dan sektor perumahan yang tumbuh semakin cepat (Pambudi, 2008). Kondisi ini menuntut adanya perkembangan infrestruktur untuk meningkatkan produktivitas kinerja dan pelayanan publik yang nyaman. Namun, pelayanan prasarana disektor lingkungan masih kurang memadai misalnya seperti distribusi air bersih, sistem drainase, penyediaan rumah bersubsidi, dan pelayanan transportasi merupakan masalah yang harus diselesaikan oleh pemerintah guna menuju masyarakat maju (Hariyanto, 2007).

Negara berkembang seperti di Indonesia sudah tidak heran lagi dengan adanya pencemaran lingkungan. Sekitar 85\% pencemaran domestik penyumbang terbesar masuk ke badan perairan (Sasongko, 2008). Sementara itu untuk dikategorikan sebagai negara maju tentu manajemen pengelolaan 
limbah dosmetik harus kurang dari 15\% yang masuk dalam perairan. Bukan hanya peran dari pemerintah tetapi juga kesadaran masyarakat untuk meningkatkan pola hidup bersih dan sehat (Yudo, 2010). Masyarakat Indonesia saat ini masih membiasakan membuang air limbah dosmetik seperti limbah air rumah tangga (grey water) ke dalam saluran drainase terbuka. Saluran drainase terbuka dikhususkan untuk mengalirkan air hujan bukan untuk limbah air rumah tangga, apabila hal ini terjadi berdampak pada timbulnya berbagai macam penyakit dan menimbulkan bau tidak sedap (Tendean dkk., 2014).

Oleh sebab itu, manajemen limbah perlu diperhatikan kandungan senyawa kimia yang berakibat meniumbulkan kerusakan lingkungan atau berpotensi menciptakan pencemaran (Marliani, 2014). Sebelum mengidentifikasi permasalahan dibutuhkan kajian khusus dan perkiraan yang matang dengan memperhitungkan sistem pengolahan, sumber pencemar, volume buangan limbah dan jenisnya, serta kegunaan bahan beracun dan berbahaya yang dihasilkan dari limbah rumah tangga atau pabrik (Wibowo dkk., 2020a; 2020b). Pentingnya merencanakan desain model IPAL yang bertujuan sebagai manajerial pengolahan sementara limbah biologis dan kimiawi di badan perairan sehingga memungkinkan air limbah tersebut dapat digunakan kembali bagi manusia seperti pemanfaatan pupuk, pestisida, dan biogas (Kurniawati \& Maqfiroh, 2019).

Penduduk Kota Kendari pada tahun 2019 berjumlah 392.830 jiwa, jika pemakaian air per orang perhari sebesar $150 \mathrm{~L}$ maka total air limbah yang dihasilkan sebesar 58.924.500 L/hari (BPS Sultra, 2020). Hal ini tentu akan meningkat seiring dengan peningkatan jumlah populasi penduduk. Berdasarkan proyeksi sebelumnya peningkatan penduduk Kota Kendari dari tahun 2010 sampai dengan 2019 sekitar 1,21\%. Penggunaan 20\% air bersih yang dimanfaatkan oleh masyarakat (air minum) (30 L) dan 80\% (120 L) air menjadi air buangan/limbah sehingga dapat diperkirakan dampak yang ditimbulkan jika air limbah tersebut langsung dibuang ke badan lingkungan tanpa pengolahan terlebih dahulu (Abubakar, 2016). Khususnya pada penelitian ini kami mengambil contoh di wilayah pemukiman Perumahan Mutiara Sartika Kota Kendari-Sulawesi Tenggara (Sultra) untuk dikembangkan perencanaan
IPAL guna menanggulangi dampak yang akan timbul dari air limbah domestik.

Perumahan ini merupakan salah satu perumahan yang terletak di Kota Kendari yang terletak di Kelurahan Alolama, Kecamatan Mandonga, Kota Kendari, Provinsi Sulawesi Tenggara (Sultra). Perumahan Mutiara Sarika memilki luas $900 \mathrm{~m}^{2}$ dan telah dibangun rumah tipe 36 dengan jumlah 60 unit. Berdasarkan kajian pendahuluan, jumlah total rumah yang akan dibangun di perumahan ini adalah sebanyak 68 unit dan saat ini memiliki 60 rumah bertipe 36. Setiap perumahan sebaiknya memiliki IPAL yang memenuhi syarat, bukan hanya memiliki tangki penampung septic tank ditiap rumah dan drainase sebagai saluran pembungan limbah cair perumahan (Safrodin dkk., 2017). Terutama limbah yang berasal dari kegiatan dapur dan kamar mandi perlu dilakukan pengolahan air limbah terlebih dahulu sehingga tidak terjadi pencemaran lingkungan. Berdasarkan kajian tersebut, kami mencoba menghitung beberapa hubungan jumlah penghuni terhadap jumlah air limbah yang dihasilkan di pemukiman Perumahan Mutiara Sartika. Berdasarkan Peraturan Menteri Lingkungan Hidup dan Kehutanan No. 68 Tahun 2016 tentang Baku Mutu Air Limbah Domestik setiap usaha dan/atau kegiatan yang menghasilkan air limbah domestik wajib melakukan pengolahan air limbah domestik yang dihasilkan (LHK, 2016).

Berdasarkan uraian di atas maka peneliti merencanakan untuk mendesain IPAL untuk dapat diaplikasikan di setiap pembangunan perumahan. Penerapan teknologi sistem up flow menjadi sistem yang baik dalam mengurangi pencemar senyawa organik terlarut maupun padatan tersuspensi pada air limbah untuk memenuhi baku mutu yang diijinkan sehingga dapat dibuang ke lingkungan dan tidak mencemari badan air serta air tanah (Nilandita dkk., 2019).

\section{METODE PENELITIAN}

Lokasi pelaksanaan penelitian ini sebagai model perencanaan unit IPAL dilakukan di Perumahan Mutiara Sartika, Kelurahan Alolama, Kecamatan Mandonga Kota Kendari, Provinsi Sultra. Jenis dan sumber data yang dilakukan mengacu pada pengelompokan berdasarkan data primer untuk memperoleh kondisi eksisting pengolahan air limbah serta sistem penyaluran air buangan yang ada. 
Penentuan kandungan bahan pencemar dalam air limbah rumah tangga dilakukan untuk mengetahui seberapa besar tingkat pencemar dalam lingkup perumahan yang sebagian besar didominasi oleh buangan limbah rumah tangga. Hasil yang diperoleh kemudian diketahui untuk desain perencanaan IPAL dengan melihat hasil analsis fisika-kimianya. Selain itu, analisis data primer dilakukan dengan mengukur langsung (observasi) jumlah penghuni dan wawancara kepada pihak perumahan dan penghuni untuk diperoleh seberapa besar limbah yang dihasilkan tiap harinya. Sementara itu, data sekunder diperoleh seperti data topografi yang diperoleh dari citra satelit google maps dan data penunjang lainya yang berhubungan dengan sistem IPAL.

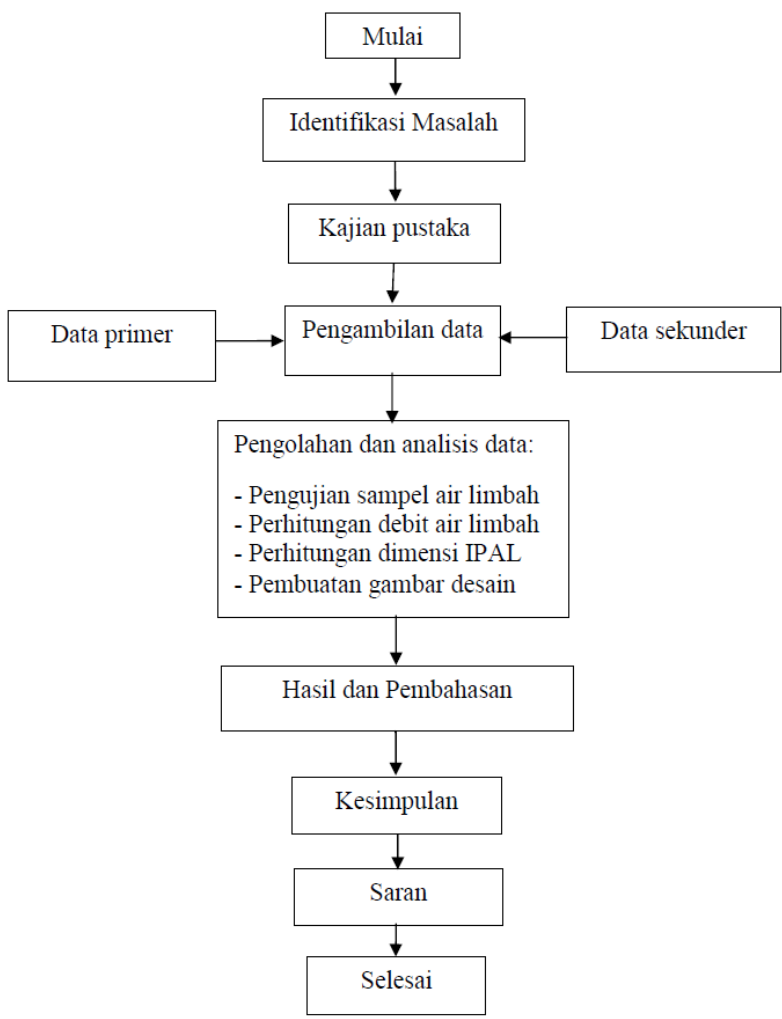

Gambar 1. Diagram Alir Proses Kajian IPAL

Perencanaan IPAL diperlukan tahapan pekerjaan yang sistematis sehingga diperoleh hasil yang optimal. Adapun prosedur kerja yang dilakukan dalam penelitian ini adalah: 1 ) Identifikasi dan observasi untuk mengetahui berbagai sumber yang dapat dimanfaatkan untuk mengumpulkan data-data terkait, 2) Tahap pengambilan sampel air limbah dengan menggunakan botol kaca untuk kemudian dilakukan pengujian di laboratorium berdasarkan parameter baku mutu air limbah domestik, 3) Pengelompokan data seperti jumlah rumah dan rencana pengembangan, jumlah penghuni, jumlah pemakaian air bersih, asumsi $80 \%$ dari pemakaian air bersih akan menjadi air limbah, dan 4) tahap perancangan dengan melakukan perhitungan geometri dimensi masing-masing unit pengolahan yang telah ditentukan berdasarkan karakteristik dan debit air limbah serta menentukan lokasi rencana desain IPAL.

\section{HASIL DAN PEMBAHASAN}

\subsection{Gambaran Umum Lokasi Perencanaan}

Studi kasus dalam pelaksanaan penelitian ini yaitu mengkaji kondisi eksisting salah satu Perumahan Mutiara Sartika sebagai dasar untuk bahan acuan terkait model perumahan yang didesain oleh berbagai macam pengembangan usaha properti di lingkup Kota Kendari. Kondisi wilayah dan keadaan geografis Perumahan Mutiara Sartika masuk dalam salah satu perumahan yang terletak di Kota Kendari (Gambar 2). Perumahan ini tepatnya terletak di Kelurahan Alolama, Kecamatan Mandonga, Kota Kendari, Provinsi Sultra. Perumahan Mutiara Sartika memiliki luas $900 \mathrm{~m}^{2}$ dan terletak di Jalan Imam Bonjol Kecamatan Mandonga Kota Kendari Ibukota Provinsi Sultra. Lokasi tersebut sangat strategis karena berada di tengah-tengah lingkungan pemukiman padat penduduk serta mudah dijangkau dengan kendaraan umum karena berada di sisi jalan poros yang menghubungkan Kota Kendari dan Kabupaten Konawe. Adapun batas-batas Perumahan Mutiara Sartika yaitu sebagai berikut, sebelah utara: perumahan penduduk Kelurahan Alolama, sebelah selatan: perumahan penduduk Kelurahan Alolama, sebelah timur: perumahan penduduk Kelurahan Alolama, sebelah barat: jalan Imam Bonjol.

Secara umum di Kota Kendari telah banyak dikembangkan usaha bidang properti dengan menyajikan kompleks perumahan bersubsidi dengan biaya murah dalam berbagai macam tipe seperti tipe $36 \mathrm{~m}^{2}$ dan 45 $\mathrm{m}^{2}$ yang ditawarkan kepada masyarakat. Walaupun dalam pelaksanaan teknis bahwa kecepatan pembangunan perumahan telah didesain secara matang oleh pihak developer, namun hal kecil seperti pengolahan limbah tidak difikirkan untuk keberlangsungan beberapa tahun kedepan. Akibatnya, kecenderungan berdampak pada kondisi lingkungan tidak sehat dan meningkatkan pencemaran lingkungan (Gambar 3). 


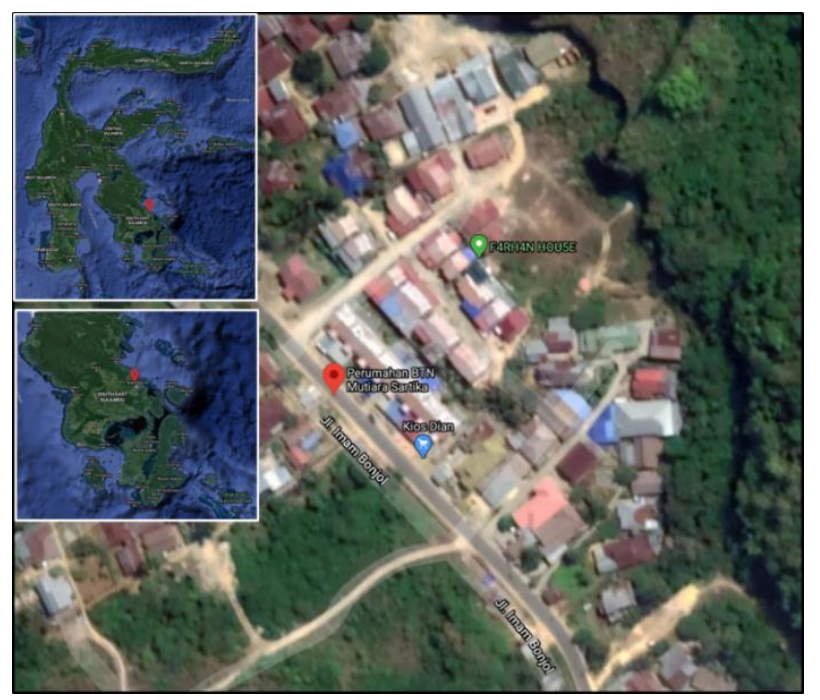

Gambar 2. Peta Lokasi Penelitian

(Sumber: Google Maps)

\subsection{Kondisi Eksisting Pengolahan Air Limbah}

Setiap perumahan tentu perlu membuat, mengembangkan dan mendesain IPAL untuk mengurangi dampak dari pencemaran lingkungan baik di sekeliling lingkungan perumahan. Saat ini beberapa perumahan hanya memiliki tangki penampung septic tank di tiap rumah dan drainase selokan sebagai saluran pembuangan limbah cair perumahan. Limbah yang terutama berasal dari kegiatan dapur dan kamar mandi langsung di buang ke drainase dan diteruskan ke sungai terdekat tanpa dilakukan pengolahan air limbah terlebih dahulu. Apabila hal ini terus dilakukan, maka akan mencemari air sungai terdekat. Maka perlu setiap limbah cair yang dihasilkan berasal dari dalam rumah dialirkan melalui saluran tertutup atau menggunakan pipa menuju ke drainase yang ada saat ini kemudian langsung dibuang ke badan lingkungan/sungai yang ada di sekitaran perumahan (Auvaria dkk., 2019).

Kondisi saat ini disekitar lokasi studi memperlihatkan bahwa kondisi eksisting drainase hanya mengacu pada saluran selokan yang diharapkannya mengalir menuju ke badan perairan. Namun perlu diperhatikan bahwa sistem drainase selokan tidak efektif dalam mengatasi limbah rumah tangga, sebab kondisi konstruksi pembuatan selokan tidak baik maka berdampak pada menghasilkan genangan tertinggal dalam selokan. Kondisi ini memicu berbagai macam penyakit dan bau yang tidak sedap di lingkungan tempat tinggal (Gambar 3). Oleh sebab itu, pentingnya mendesain perencanaan pengembangan IPAL dilingkup perumahan dengan memikirkan beberapa faktor seperti limbah yang dihasilkan oleh rumah tangga dan sampah zat adiktif hasil penggunaan air bersih masyarakat.

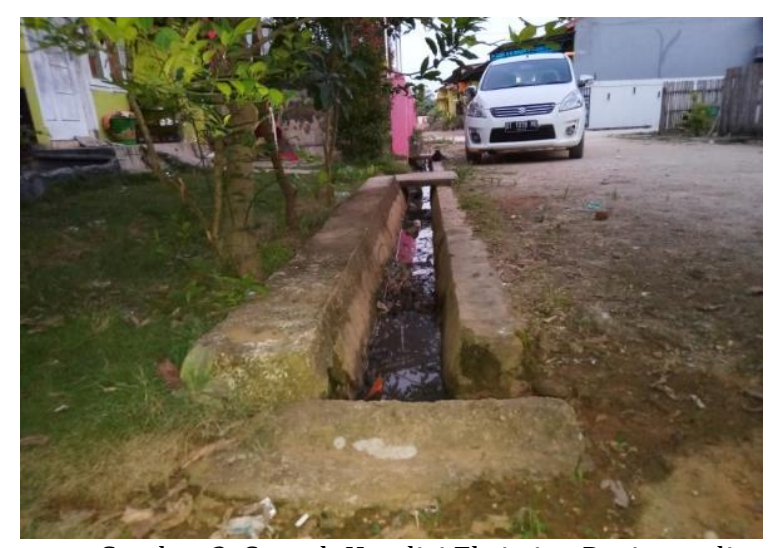

Gambar 3. Contoh Kondisi Eksisting Drainase di Perumahan Mutiara Sartika

\subsection{Karakteristik Limbah Cair Perumahan}

Analisis awal dalam penelitian ini mencari tahu apakah hasil air limbah yang dialirkan dalam sistem drainase selokan telah tercemar atau tidak. Selain itu, berdasarkan kajian fisika dan kimia sehingga kita dapat memperoleh/ menyimpulkan model dan pengembangan model IPAL yang baik untuk diterapkan pada kompleks perumahan.

Pada umumnya limbah cair domestik dari hasil buangan rumah tangga dapat berasal dari beberapa sumber seperti ruang dapur dan kamar mandi. Parameter limbah cair dapat diketahui dengan cara melakukan uji laboratorium untuk mengetahui besarnya kandungan pencemar. Berdasarkan Keputusan Menteri Lingkungan Hidup dan Kehutanan No. 68 Tahun 2016 tentang Baku Mutu Air Limbah Domestik menyatakan bahwa setiap usaha dan/atau kegiatan yang menghasilkan air limbah domestik wajib melakukan pengolahan air limbah domestik yang dihasilkan (LHK, 2016). Hasil analisa laboratorium menyatakan beberapa parameter limbah cair yang dihasilkan disekitaran Perumahan Mutiara Sartika melebihi baku mutu yang telah ditentukan. Adapun kualitas limbah cair dapat dilihat pada Tabel 1.

Perencanaan desain IPAL dalam penelitian ini dibuat untuk tipe perumahan yang pada dasarnya lebih banyak menghasilkan limbah rumah tangga. Kandungan limbah rumah tangga cenderung didominasi dengan dihasilkannya bahanbahan kimia sisa penggorengan (lemak), sisa makanan, limbah detergen, dll. Oleh karena itu, langkah awal dalam penelitian ini dilakukan 
analisis kandungan air limbah secara umum melihat komposisi secara fisika-kimia hasil buangan limbah pada sistem drainase di Perumahan Mutiara Sartika seperti yang disajikan pada Tabel 1.

Tabel 1. Hasil Uji Parameter Air Limbah di Perumahan Mutiara Sartika

\begin{tabular}{lcccc}
\hline No & Parameter & Satuan & Hasil & $\begin{array}{c}\text { Baku } \\
\text { mutu }\end{array}$ \\
\hline 1. & $\begin{array}{c}\text { pH (derajat } \\
\text { keasaman) }\end{array}$ & $\mathrm{mg} / \mathrm{L}$ & 6,55 & $6-9$ \\
\hline 2 & $\begin{array}{c}\text { Total padatan } \\
\text { tersuspensi (TSS) }\end{array}$ & $\mathrm{mg} / \mathrm{L}$ & 620 & 30 \\
\hline 3. & Amoniak NH & $\mathrm{mg} / \mathrm{L}$ & 83,25 & 10 \\
\hline 4. & $\begin{array}{c}\text { Chemical oxygen } \\
\text { demand (COD) }\end{array}$ & $\mathrm{mg} / \mathrm{L}$ & 266,80 & 100 \\
\hline 5. & $\begin{array}{c}\text { Biologycal oxygen } \\
\text { demand (BOD) }\end{array}$ & $\mathrm{mg} / \mathrm{L}$ & 128,90 & 30 \\
\hline 6. & Minyak lemak & $\mathrm{mg} / \mathrm{L}$ & 1,0 & 5 \\
\hline & & & & \\
\hline
\end{tabular}

Tabel 1 menunjukkan bahwa hasil kandungan limbah yang diambil dari sistem drainase sangat beragam dan memilki nilai diatas Baku mutu. Ditinjau dari parameter fisika seperti TSS menunjukkan bahwa limbah air rumah tangga memiliki tingkat kekeruhan yang sangat tinggi. Hal ini bukan diakibatkan oleh partikel namun banyaknya air limbah yang tercampur dan terakumulasi dalam air tersebut sehingga meningkatkan kekeruhan air (Ulya \& Bowo, 2014). Disisi lain, analisis parameter kimia juga sangat penting ditentukan karena memberikan dampak signifikan dalam mengetahui dampak dari pencemaran limbah rumah tangga. Berdasarkan hasil analisis kandungan amoniak $\left(\mathrm{NH}_{3}\right)$ memberikan dampak yang signifikan 8 kali lebih besar dibandingkan baku mutu. Dicurigai bahwa tingginya kandungan $\mathrm{NH}_{3}$ berasal dari hasil buangan sisa makanan yang mengandung protein sehingga sebagian larut dalam air limbah. Selain itu, limbah ini juga memicu munculnya bau tidak sedap dari air limbah karena menjadi media berkembang biaknya bakteri.

Selain itu, nilai COD dilakukan untuk ukuran pencemaran oleh zat - zat organik yang dapat dioksidasi melalui proses biologis atau kimia sehingga menyebabkan berkurangnya oksigen terlarut dalam perairan (Wibowo dkk., 2017, 2018). Tingginya kandungan COD dalam air limbah merupakan tingkat pencemaran bahan pencemar organik dalam jumlah tinggi (Khoiri, Miftakhul dkk., 2020). Hasil analisis COD menunjukkan bahwa tingkat pencemaran sangat tinggi dengan nilai 266,8 melebihi standar baku mutu yang ditetapkan. Ini jelas menunjukkan bahwa pencemaran air limbah rumah tangga lebih banyak didominasi mengandung senyawa organik pencemar. Seperti halnya penentuan COD, nilai BOD merupakan jumlah oksigen yang dibutuhkan untuk mengoksidasi senyawa organik yang terkandung dalam air limbah. Nilai BOD ditunjukkan 4 kali lebih besar dibandingkan nilai baku mutu sehingga air buangan rumah tangga tergolong sudah tercemar.

Kami juga melakukan menganalisis kandungan minyak dalam air limbah rumah tangga yang diambil dari sistem drainase Perumahan Mutiara Sartika, memperlihatkan bahwa hasil dibawah standar baku mutu air limbah domestik. Kurangnya nilai kadar minyak terkandung dalam air limbah kemungkinan telah mudah terakumulasi dalam air, mudah terdegradasi oleh bantuan bakteri, dan terjerap dalam pori-pori drainase. Secara harfiah bahwa minyak terbuat dalam air limbah tidak begitu banyak sebab perbandingan minyak jauh lebih kecil dibandingkan penggunaan air sisa penggunaan rumah tangga. Walaupun begitu, air limbah yang dibuang ke sistem drainase telah tercemar sehingga berdampak pada timbulnya berbagai macam penyakit, bau yang tidak sedap, dan tingginya pertumbuhan \& perkembangan spesies mikroskopik terganggu.

\section{Desain Perencanaan IPAL Perumahan}

Berdasarkan hasil kajian awal pencemaran air limbah kemudian kami mencoba merencanakan desain proses pengolahan air limbah dengan metode biofilter "Up Flow" ini terdiri dari bak pengumpul, bak pemisah lemak, bak ekualisasi, bak pengendap awal, bak septik, bak biofilter yang diisi dengan pasir kuarsa/silika, arang aktif zeoit atau media lain dan bak pengendap akhir.

Pada penelitian ini, perencanaan seluruh air limbah yang berasal dari aktivitas kegiatan perumahan dialirkan ke bak pengumpul. Bak pengumpul yang direncanakan adalah tipe gravitasi sederhana. Metode ini dirasa sangat mudah didesain dan efisien karena sistem penyaluran air limbah dari tempat yang tinggi ketempat yang lebih rendah tanpa membutuhkan energi. Namun yang perlu diperhatikan dalam proses perencanaan pembuatan IPAL adalah harus memperhatikan teknik pembuatan sistem pengaliran dari alat saniter langsung menuju pipa yang dikenal dengan istilah Shallow sewer (Khoiri dkk., 
2020). Adapun skema pengolahan dalam perencanaan IPAL yang akan direncanakan digambarkan dalam Gambar 4.

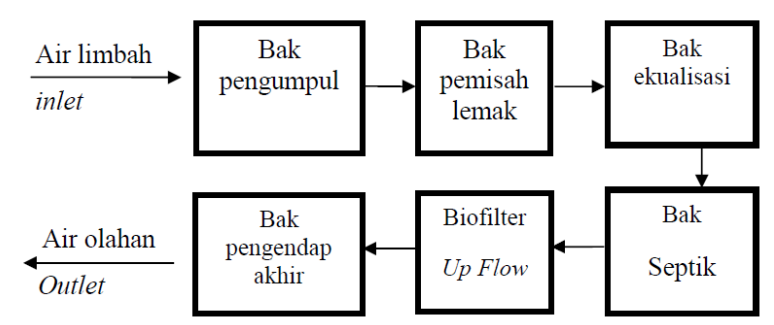

Gambar 4. Skema Proses Pengolahan Air Limbah dengan Sistem Up Flow

Desain bak pengumpul berfungsi untuk tahap awal penyaringan kotoran dari limbah organik skala besar sepert lemak, minyak, bungkus plastik, dll yang ikut masuk dalam lubang pembuangan rumah. Selanjutnya air limbah dialirkan ke bak pemisah lemak guna memisahkan bahan buangan kegiatan dapur. Selain itu, pada bak ini juga memfasilitasi proses pengendapan kotoran seperti pasir, tanah atau senyawa padatan yang tidak dapat terurai secara biologis. Masuk ke bak ekualisasi berfungsi sebagai peredaman variasi laju aliran aliran konstan atau hampir konstan dan dapat diterapkan dalam sejumlah situasi yang berbeda, tergantung karakteristik sistem pengumpulan.

Air limpasan dari bak ekualisasi selanjutnya dialirkan ke bak septik dimana bak septik berfungsi memisahkan antara padatan dan cairan menggunakan sistem pengendapan secara gravitasi. Unit ini juga dapat menurunkan konsentrasi BOD/COD dalam aliran sehingga membantu menurunkan beban pengolahan biologis pada tahapan pengolahan berikutnya. Bak septik memiliki fungsi yang sama seperti ekualisasi sebagai media penyimpanan sementara yang nantinya dapat dipisahkan secara baik di media up flow berbasis pemanfaatan daya alir dari bawah ke atas. Metode ini berfungsi menurunkan kesadahan beberapa senyawa organik, kandungan COD dan BOD serta total padatan tersuspensi. Sayangnya tidak dapat untuk mengurangi kandungan amoniak, bahan detergen, dan hidrogen sulfida. Kelemahan lainnya membutuhkan pengolahan tambahan seperti efisiensi reduksi bakteri pathogen dan nutrien rendah, serta membutuhkan start up yang lama. Metode ini dirancang untuk tahan terhadap shock loading yaitu tahan terhadap guncangan dan tekanan yang sering ditemukan beberapa permasalahan dalam proses perawatan. Selain itu, biofilter up flow tidak membutuhkan banyak energi listrik, biaya operasional rendah (tidak mahal), dan tingkat efisiensi BOD/COD dan TSS sangat tinggi (Siregar dkk., 2016).

Beberapa media penyaring dapat digunakan seperti zeolit, pasir silika, dan arang aktif yang bertujuan untuk mempercepat proses penguraian dengan bahan material dan penambahan media mikroorganisme untuk menguraikan zat organik yang berada di dalam air limbah. Ini sangat cocok untuk tumbuh kembang mikroorganisme pendegradasi bahan organik terkandung dalam air limbah. Berdasarkan skema Gambar 4 terakhir masuk dalam bak pengendapan akhir guna memisahkan dan mengendapkan beberapa limbah padatan tersuspensi yang masih ikut dalam aliran. Melalui beberapa tahap pemisahan jelas bahwa hasil luaran air limbah masih cukup aman untuk dibuang ke perairan. Perhitungan dasar dari perencanaan pembuatan IPAL, dapat menerapkan perhitungan jumlah timbulan air limbah rata-rata per hari adalah 8-\% dari pemakaian air bersih rata-rata per hari. Konsumsi air bersih di Perumahan Mutiara Sartika dapat dihitung sebagai berikut
Kebutuhan air bersih Jumlah rumah Jumlah orang/rumah Konsumsi air bersih

Jumlah limbah

$$
\begin{aligned}
& =150 \mathrm{~L} / \text { hari/orang } \\
& =68 \mathrm{rumah} \\
& =5 \text { orang/rumah (asumsi penghuni type } 36) \\
& =\text { kebutuhan air bersih } \times \text { jumlah rumah } \times \text { Jumlah orang/rumah } \\
& =150 \mathrm{~L} / \text { hari/orang } \times 68 \mathrm{rumah} \times 5 \text { orang/rumah } \\
& =51.000 \mathrm{~L} / \text { hari }
\end{aligned}
$$$$
=\text { konsumsi air bersih } \times(x)
$$$$
=51.000 \mathrm{~L} / \text { hari } \times 80 \%
$$$$
=40.800 \mathrm{~L} / \text { hari }
$$$$
=40.8 \mathrm{~m}^{3} / \text { hari }
$$ 
Tabel 2. Rekapitulasi Dimensi dan Waktu Tinggal pada Unit Pengolahan

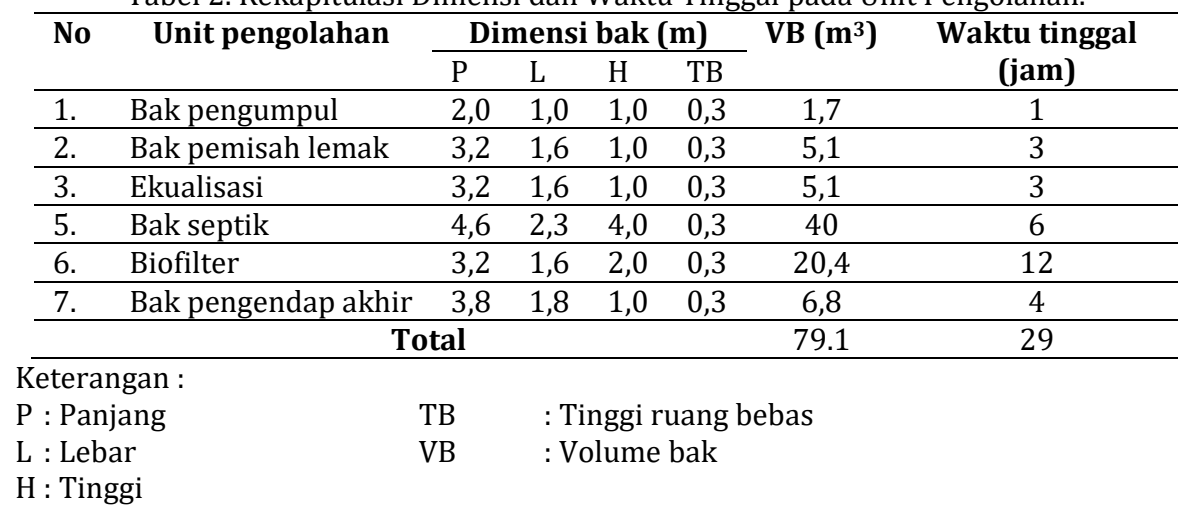

Berdasarkan perhitungan perencanaan pengembangan IPAL, maka ditetapkan dimensi bak dan waktu tinggal air limbah pada masing-masih unit pengolahan (Tabel 2). Berdasarkan Tabel 2 bak pengumpul direncanakan berbentuk persegi panjang yang bertujuan untuk meningkatkan kemampuan daya tampung dan juga memfilter beberapa zat pengotor air limbah seperti lemak, minyak, plastik hasil buangan rumah tangga. Hasil tersebut dapat disimpulkan bahwa desain perencanaan penampungan IPAL berbentuk geometri seperti balok dengan memperhatikan bangun ruang yang dibatasi oleh 6 sisi yang berbentuk persegi panjang atau persegi dengan ukuran berbeda, 6 sisi tersebut terdiri dari 3 pasang sisi yang sejajar dan kongruen.

Perhitungan matematis kapasitas pengolahan $(\mathrm{Q})=40,8 \mathrm{~m}^{3} / \mathrm{Hari}=1,7 \mathrm{~m}^{3} / \mathrm{jam}$ dengan waktu tinggal di dalam bak (hidraulic retention time) $=1$ jam. Mendesain bak penampung untuk sistem limbah domestik perlu mempertimbangkan pemisahan senyawa organik seperti minyak, detergen, dan partikel lainnnya. Senyawa-senyawa ini sangat stabil di alam karena struktur yang kompleks dan sulit didekomposisikan oleh beberapa bakteri. Oleh sebab itu, limbah ini dapat menimbulkan berbagai macam masalah di saluran maupun dalam IPAL. Secara fisik kondisi keberadaan berada di dalam air permukaan sehingga berdampak pada pertumbuhan biota dibawah air dan mengganggu estetika di badan air.

Umumnya bak ekualisasi didesain dengan perhitungan debit maksimal pada saat jam puncak dengan menentukan peak factor dari pemakaian air bersih yang menghasilkan air limbah. Limbah yg keluar dari bak ekualisasi debit akan berfluktuasi menghasilkan debid rata-rata. Pada penelitian ini bak ekualisasi yang diusulkan berbentuk persegi panjang dengan sistem pengendapan gravitasi tanpa penambahan zat kimia tertentu. Biasanya bak ekualisasi digunakan untuk mengatasi beberapa masalah operasional seperti variasi debit dan kualitas penyaringan terhadap limbah cair yang masuk kebagian unit-unit pengolahan limbah. Bak ini memiliki peredaman variasi laju aliran limbah secara konstan sesuai dengan keinginan dengan meningkatkan karakteristik sistem pengumpulan limbah. Desain lubang masuk (inlet) harus berada di atas dari aliran keluar (outlet) agar dapat proses penampungan dan aliran maksimal.

Terkadang dalam beberapa pengolahan air limbah yang besar, dari bak ekualisasi dapat disalurkan ke bak-bak penampungan (digester) untuk proses penguraian secara mikroba atau kimiawi. Namun untuk skala perumahan layak huni penggunaan tersebut memakan lahan yang cukup besar, sehingga dapat digantikan dengan bak penampungan septik. Sementara itu, bak pengendap akhir ini memiliki fungsi yang sama seperti bak septik. Konsentrasi padatan yang masuk sudah berkurang $80 \%$ untuk BOD dan $80 \%$ untuk COD. Luas kebutuhan lahan yang diperlukan dalam Perencanaan IPAL sesuai dengan rencana pengembangan perumahan yaitu sebesar 36,78 $\mathrm{m}^{2}$. Adapun rekapitulasi kebutuhan luas lahan dalam Perencanaan IPAL dapat dilihat dalam Tabel 3.

Tabel 3. Rekapitulasi Kebutuhan Luas Lahan IPAL

\begin{tabular}{llc}
\hline No. & Unit pengolahan & Luas lahan $\left(\mathbf{m}^{\mathbf{2}} \mathbf{)}\right.$ \\
\hline 1. & Bak pengumpul & 2,00 \\
\hline 2. & Bak pemisah lemak & 5,12 \\
\hline 3. & Ekualisasi & 5,12 \\
\hline 5. & Bak septik & 10,58 \\
\hline 6. & Biofilter & 5,12 \\
\hline 7. & Bak pengedap akhir & 8,84 \\
\hline & Total & $\mathbf{3 6 , 7 8}$
\end{tabular}




\section{KESIMPULAN}

Berdasarkan hasil penelitian ini dengan kebutuhan konsumsi air bersih sebesar 150 L/hari/orang dengan jumlah perumahan 68 rumah type 36 dan 5 orang/rumah maka jumlah limbah yang dihasilkan sebesar 40.8 $\mathrm{m}^{3} /$ hari. Sehingga dimensi bak penampungan air limbah yang dibangun berbentuk persegi panjang dengan total volume penampungan $79,1 \mathrm{~m}^{3}$ dengan perkiraan waktu tinggal selama 29 jam memperhatikan beberapa fungsi unit pengolahan. Berdasarkan hasil penelitian ini diharapkan dapat membantu untuk mengaplikasikan desain IPAL sederhana untuk pembangunan perumahan.

\section{DAFTAR PUSTAKA}

Abubakar, A. (2016). Dampak sertifikasi guru terhadap kualitas pendidikan pada madrasah aliyah di kota kendari. AlQalam, 21(1), 117-128.

Arsyad, L. (2014). Ekonomi pembangunan. 5, $1-46$.

http://repository.ut.ac.id/3950/1/ESPA 4229-M1.pdf

Auvaria, S. W., Nilandita, W., \& Nengse, S. (2019). Perencanaan Sistem Manajemen Lingkungan pada Aspek Air Bersih, Limbah, Energi, dan Penghijauan di Pondok Pesantren (Studi Kasus: Pondok Pesantren An-Najiyah Surabaya). Al-Ard: Jurnal Teknik Lingkungan, 4(2), 36-45.

BPS Sultra. (2020). Provinsi Sulawesi Tenggara dalam Angka 2020 (Issue 1). https://doi.org/10.16309/j.cnki.issn.100 7-1776.2003.03.004

Hariyanto, A. (2007). Strategi Penanganan Kawasan Kumuh Sebagai Upaya Menciptakan Lingkungan Perumahan dan Permukiman yang Sehat (Contoh Kasus: Kota Pangkalpinang). Jurnal Perencanaan Wilayah Dan Kota UNISBA, 7(2), 11-37.

Khoiri, Miftakhul, Mauludiyah, Mauludiyah, \& Noverma, N. (2020). Analisa Dampak Pembuangan Limbah Pengolahan Tepung Ikan Terhadap Kualitas Air Sungai dan Ekosistem Mangrove di. Al-Ard: Jurnal Teknik Lingkungan, 5(2), 91-97.

Kurniawati, Y., \& Maqfiroh, N. (2019). Analisis Effluent Limbah Cair Pt Dnp Indonesia. Pulogadung, Jakarta Timur. Jurnal Ilmiah Kesehatan, 11(1), 64-72.

LHK. (2016). "Baku Mutu Air Limbah Domestik" (p. No. 68 Tahun 2016). Jakarta.

Marliani, N. (2014). Pemanfaatan limbah rumah tangga (sampah anorganik) sebagai bentuk implementasi dari pendidikan lingkungan hidup. Formatif: Jurnal Ilmiah Pendidikan MIPA, 4(2), 124132.

Nilandita, W., Pribadi, A., Nengse, S., Auvaria, S. W., \& Nurmaningsih, D. R. (2019). Studi Keberlanjutan IPAL Komunal di Kota Surabaya ( Studi Kasus di RT 02 RW 12 Kelurahan Bendul Merisi Kota Surabaya ). Al-Ard: Jurnal Teknik Lingkungan, 4(2), 46-54.

Pambudi, A. (2008). Analisis nilai ekonomi lahan (land rent) pada lahan pertanian dan permukiman di Kecamatan Ciampea, Kabupaten Bogor. Skripsi. Bogor: Fakultas Pertanian IPB. https://repository.ipb.ac.id/handle/123 456789/1385

Safrodin, A., Mangkoedihardjo, S., \& Yuniarto, A. (2017). Desain IPAL Subsurface Flow Constructed Wetland Di Rusunawa Grudo Surabaya. IPTEK Journal of Proceedings Series, 3(5), 198-207.

Sasongko, L. A. (2008). Pencemaran Air Sungai Tuk Akibat Air Limbah Domestik (Studi Kasus Kelurahan Bendan Ngisor Dan Kelurahan Sampangan Kecamatan Gajah Mungkur Kota Semarang). Jurnal Ilmiah Momentum, 4(1), 1-9.

Siregar, R. R. P. P., Razif, M., \& Mardyanto, M. A. (2016). Perbandingan DED IPAL Anaerobic Filter dengan Upflow Anaerobic Sludge Blanket untuk Tempat Pelelangan Ikan (TPI) Sedati di Kabupaten Sidoarjo. Jurnal Teknik ITS, 5(2), D233-D236.

Tendean, C., Tilaar, S., \& Karongkong, H. H. (2014). Pengelolaan Air Limbah Domestik di Permukiman Kumuh di Kelurahan Calaca dan Istiqlal Kecamatan Wenang. SABUA, 6(3), 293-306.

Ulya, A., \& Bowo, D. M. (2014). Perencanaan SPAL dan IPAL Komunal di Kabupaten Ngawi (Studi Kasus Perumahan Karang Tengah Prandon, Perumahan Karangasri dan Kelurahan Karangtengah). 3(2), 157161.

Wibowo, D., Maulidiyah, Ruslan, Azis, T., \& Nurdin, M. (2018). A high-performance electrochemical sensor based on FeTiO3 synthesis coated on conductive substrates. Analytical and Bioanalytical Electrochemistry, 10(4), 465-477.

Wibowo, D, Ruslan, Maulidiyah, \& Nurdin, M. (2017). Determination of COD based on 
Photoelectrocatalysis of FeTiO3.TiO2/Ti

Electrode. IOP Conference Series:

Materials Science and Engineering. https://doi.org/10.1088/1757-

899X/267/1/012007

Wibowo, D., Muzakkar, M. Z., Saad, S. K. M., Mustapa, F., Maulidiyah, M., Nurdin, M., \& Umar, A. A. (2020a). Enhanced visible light-driven photocatalytic degradation supported by $\mathrm{Au}-\mathrm{TiO} 2$ coral-needle nanoparticles. Journal of Photochemistry and Photobiology A: Chemistry, 112589.

Wibowo, D., Sufandy, Y., Irwan, I., Azis, T., Maulidiyah, M., \& Nurdin, M. (2020b). Investigation of nickel slag waste as a modifier on graphene-TiO2 microstructure for sensing phenolic compound. Journal of Materials Science: Materials in Electronics, 1-9.

Yudo, S. (2010). Kondisi Kualitas Air Sungai Ciliwung Di Wilayah DKI Jakarta Ditinjau Dari Paramater Organik, Amoniak, Fosfat, Deterjen Dan Bakteri Coli. Jurnal Air Indonesia, 6(1), 34-42. 